\title{
Molecular Cloning of a Polymorphic DNA Endonuclease Fragment Associates Insulin-dependent Diabetes Mellitus with HLA-DQ
}

\author{
Birgitte Michelsen and Åke Lernmark \\ Hagedorn Research Laboratory, DK-2820 Gentofte, Denmark
}

\begin{abstract}
A BamHI 3.7-kilobase (kb) fragment detected by an HLA-DQ $\beta$-chain complementary DNA (CDNA) probe and negatively associated with insulin-dependent diabetes mellitus (IDDM) was cloned and sequenced to localize the polymorphism to BamHI sites in intervening sequences of an HLA-DQ $\boldsymbol{\beta}$-chain gene. A probe of the first intervening sequence (IVS 1) showed the BamHI 3.7-kb fragment in 6 of 17 HLA-DR3/4 controls but in 0 of 13 DR-identical IDDM patients. All IDDM patients (13 of 13) had BamHI fragments of 12 and $4 \mathrm{~kb}$, detected in 9 of 17 controls $(P<0.02)$. The simple restriction fragment length polymorphism pattern of the IVS 1 probe was exploited by comparing 113 IDDM patients with 177 healthy controls to show increased prevalences in IDDM of the 12-kb $(P<0.0001)$ and 4-kb $(P<0.0001)$ fragments. In IDDM patients younger than 20 yr at onset, $98 \%$ were 12- and/or 4-kb positive, compared with $63 \%$ of controls $(P<0.0001)$, giving a relative risk of 91.8 for individuals with both fragments. The 12-kb fragment was linked to HLA-DR4, and the 4-kb fragment to HLA-DR3. Both serologic markers were split and a non-DR3/non-DR4 IDDM patient was 4-kb positive. HLA-DQ seems therefore closer, than HLA-DR, to an IDDM susceptibility gene.
\end{abstract}

\section{Introduction}

Type 1 (insulin-dependent) diabetes mellitus (IDDM) ${ }^{1}$ affects primarily children and young adults and is the most common chronic metabolic disorder in childhood (see references 1-3 for reviews). The etiology is still unknown although virus or other environmental factors (1-4) have been implicated. The pathogenesis involves autoimmune phenomena, including the presence of insulitis $(5,6)$, islet cell autoantibodies (reviewed in references 2 and 3), or other organ-specific autoimmune diseases $(2,7)$. In contrast to the common view of an acute and dramatic onset, IDDM seems to evolve after immune abnormalities are present but long before the clinical onset $(8,9)$. The specific evanescence of the pancreatic $\beta$ cells has yet to be clarified, but it is possible that certain autoantigens, such as an $M_{\mathrm{r}} 64,000$ protein detected by IDDM sera (10), direct the immune system

Address reprint requests to Dr. Lernmark, Hagedorn Research Laboratory, Niels Steensenvej 6, DK-2820 Gentofte, Denmark.

Received for publication 29 July 1986 and in revised form $25 \mathrm{No}$ vember 1986.

1. Abbreviations used in this paper: IDDM, insulin-dependent diabetes mellitus; NIDDM, non-insulin-dependent diabetes mellitus; RFLP, restriction fragment length polymorphism.

J. Clin. Invest.

(C) The American Society for Clinical Investigation, Inc. 0021-9738/87/04/1144/09 \$1.00

Volume 79, April 1987, 1144-1152 to the $\beta$ cells. The disease seems to run in families, but the mode of inheritance has not been clarified. A familial hyperautoreactivity may be a prerequisite for IDDM to develop (11), and the adverse autoimmune reaction against the pancreatic $\beta$ cells may be controlled by HLA genes in the major histocompatibility complex, inasmuch as $>90 \%$ of IDDM patients are HLA-DR3 and/or 4 positive $(12,13)$.

Although these HLA-DR specificities account for nearly all IDDM patients, their frequencies in the background population amount to nearly $60 \%(12,13)$. The HLA-DR $3 / 4$ genotype is associated with the highest risk of developing IDDM. The concordance rate for IDDM among monozygotic twins remains, however, below $50 \%$ (14) and the risk of an HLA-DR-identical sibling developing IDDM is only $12 \%-24 \%(2,13)$. HLA typing is therefore insufficient in predicting a development of IDDM also because recent epidemiologic data indicate that only $13 \%$ of new IDDM patients have an affected parent or sibling (15). The question, therefore, remains whether there exist other genes linked to HLA-DR, which would confer a greater risk for IDDM to develop. The present study describes an approach by which to define disease susceptibility genes at the genomic level by the isolation of locus-specific genomic DNA probes derived from a polymorphic DNA fragment.

Recently, we $(16,17)$ and others $(18,19)$ described HLADQ-region $\beta$-chain DNA endonuclease fragments that differ among HLA-DR-identical healthy and IDDM individuals. These observations are important, because they suggest that DNA polymorphism may define better the susceptibility to develop IDDM or other disorders found to be associated with HLA. The restriction fragment length polymorphisms (RFLP) detected by an HLA-DQ $\beta$-chain complementary DNA (cDNA) probe are extensive and reveal complex endonuclease fragment patterns (16-24). Because we found that HLA-DR-identical control and IDDM individuals differ with respect to a BamHI 3.7-kb fragment detected with an HLA-DQ $\beta$-chain cDNA probe $(16,17)$, we decided to clone this fragment from an HLA-DR4 ${ }^{+}$chromosome of a healthy individual $(a)$ to establish its origin, $(b)$ to determine the molecular basis of the RFLP, and $(b)$ to test whether a fragment of the cloned BamHI 3.7-kb fragment could be used to obtain a less complex fragment pattern to increase the precision of RFLP analyses used for the detection of individuals that risk developing IDDM.

\section{Methods}

Subjects. Frozen lymphocytes from HLA-DR $3 / 4^{+}$individuals were obtained from 13 patients with IDDM and 17 healthy individuals. The samples were kindly made available for study by Drs. A. Svejgaard and P. Platz, the Tissue Typing Laboratory, Rigshospitalet, Copenhagen and by F. Kissmeyer-Nielsen, Tissue Typing Laboratory, Kommune Hospitalet, Aarhus, Denmark. Blood collected in EDTA was also obtained from 177 healthy blood donors at the Blood Bank, Gentofte County Hospital, Gentofte, Denmark. There were 42 (24\%) females and 131 (76\%) males. At routine clinical visits at the Steno Memorial Hospital, 
Gentofte, Denmark, $10-20 \mathrm{ml}$ of blood, collected in the presence of heparin, was obtained at random from 113 patients, $38(34 \%)$ females, $75(66 \%)$ males, with ages varying between 2 and $66 \mathrm{yr}$ at onset of IDDM (Fig. 1), and also from 46 patients with non-insulin-dependent diabetes mellitus (NIDDM). The age distribution at the time of admittance (Fig. 1) was compatible with that previously reported for Denmark (25). All the blood samples were obtained during routine visits, and were coded and analyzed in a random fashion. The fragments detected in the RFLP analysis were scored and recorded without the observer knowing the origin of the sample.

Cloning of restriction fragment. In our previous family study it was demonstrated that the RFLP observed after hybridization with an HLADQ $\beta$-chain probe was linked to HLA-DR (17) and that the BamHI 3.7$\mathrm{kb}$ fragment appeared on three of six HLA-DR4-containing chromosomes in healthy individuals, but in 0 of 13 of the diabetic DR4-containing chromosomes (17). We selected one informative Swedish family without history of either IDDM or NIDDM to clone a BamHI 3.7-kb fragment from an HLA-DR4-containing chromosome (26). The individual donating blood for cloning was a healthy HLA-DR2/4, 3.7-kb fragment-positive mother with two daughters. Her husband is HLADR3/7 and their two daughters are HLA-DR2/3 and 4/7, respectively. The HLA-DR4/7 daughter also has the BamHI 3.7-kb fragment, which is therefore present on the HLA-DR4-containing chromosome of the mother. Mononuclear cells were obtained from $30 \mathrm{ml}$ of blood by FicollHypaque gradient centrifugation and the DNA was extracted as described below. $\sim 50 \mu \mathrm{g}$ of DNA was digested with BamHI and electrophoresed in a $1 \%$ agarose gel along with appropriate molecular weight markers. The 3.4-3.8-kb region was sliced from the gel and the DNA fragments recovered by electroelution. This fraction of fragments was ligated into the BamHI site of pUC8 and used to transform Escherichia coli JM10528. Recombinant plasmids were recognized as those giving rise to white colonies on L-broth plates with $20 \mu \mathrm{g} / \mathrm{ml}$ each of isopropyl thiogalactoside and 5-bromo-4-chloro-3-indolyl- $\beta$-D-galactopyranoside, and were screened for HLA-DQ-related sequences by in situ hybridization on nitrocellulose filters with the nick-translated DQ $\beta$ cDNA probe (26).

DNA preparation. Mononuclear cells, obtained from $10 \mathrm{ml}$ of blood by Ficoll-Hypaque gradient centrifugation, were digested overnight at $37^{\circ} \mathrm{C}$ in $0.02 \%$ proteinase $\mathrm{K}$ and $1 \%$ (wt/vol) SDS in $10 \mathrm{mM}$ Tris-HCl buffer (pH 7.4) containing $1 \mathrm{mM}$ EDTA. After phenol and chloroform extractions, the DNA was precipitated with ethanol and resuspended in Tris-EDTA buffer.

Genomic blots. Lymphocyte DNA (10-20 $\mu \mathrm{g})$ was digested with restriction enzymes according to the suppliers (Boehringer, Mannheim, Federal Republic of Germany) specifications, electrophoresed overnight at $40 \mathrm{~V}$ in $1 \%$ flatbed agarose gels, and then transferred to HybondN nylon membranes (Amersham International, Buckinghamshire, United Kingdom) using the methods described by the supplier.

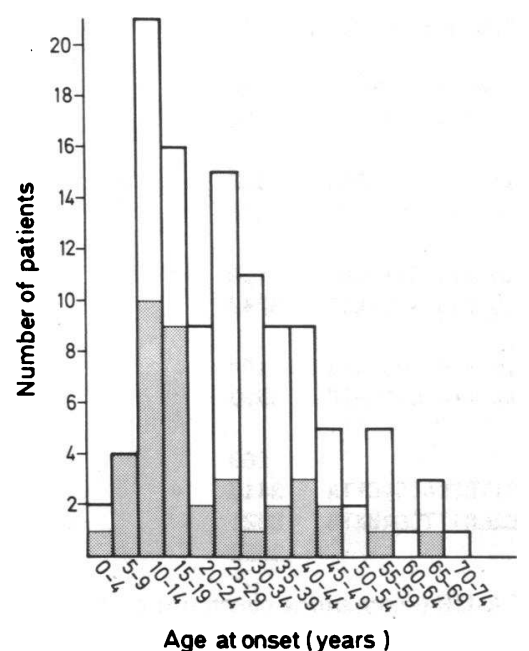

Figure 1. Age variation among the 113 IDDM patients studied for RFLP polymorphism with the HLA-DQ $\beta$ chain IVS 1 gene probe. The dotted bars represent the 39 (35\%) patients who were positive for the 12- and 4-kb BamHI restriction fragments detected with the IVS 1 gene probe.
Hybridizations. Filters were prehybridized for $2-16 \mathrm{~h}$ in $50 \%$ formamide, $5 \times$ standard saline citrate (SSC), $5 \times$ Denharts solution, $50 \mathrm{mM}$ $\mathrm{Na}_{2} \mathrm{PO}_{4}$ (pH 6.5), and $0.5 \mathrm{mg} / \mathrm{ml}$ denatured salmon sperm DNA. Hybridization was performed overnight in $50 \%$ formamide, $1 \times$ Denharts solution, $20 \mathrm{mM} \mathrm{Na}_{2} \mathrm{PO}_{4}$ (pH 6.5), $10 \%$ dextran sulphate, $0.2 \mathrm{mg} / \mathrm{ml}$ denatured salmon sperm DNA, and $10^{6} \mathrm{dpm} / \mathrm{ml}$ denatured probe. Washing stringency was $0.1 \times \mathrm{SSC}$ at $55^{\circ} \mathrm{C}$.

Probes. The DQ $\beta$ cDNA probe was derived from the plasmid pII$\beta 1$ (27) by digestion with PstI and EcoR1, after which the 800-base pair (bp) fragment was eluted from agarose melting at low temperature (BioRad Laboratories, Richmond, CA).

A subclone of the BamHI 3.7-kb fragment cloned in pBR322 was used to construct the first intervening sequence (IVS 1) probe. The recombinant plasmid was digested with the endonuclease RSA1 to yield a fragment, which contains $154 \mathrm{bp}$ of intervening sequence and $12 \mathrm{bp}$ of the second exon which codes for the first domain of the HLA-DQ $\beta$ chain, as well as the portion of pBR322 that ranges from the BamHI site in position 375 to the RSAl site in position 2281 . This 2.072-bp fragment was purified after agarose gel electrophoresis in a low-temperature melting-point agarose. Labeling of probes was by nick-translation, using $\alpha-\left[{ }^{32} \mathrm{P}\right]$ deoxy CTP (Amersham International) at $30 \mathrm{TBq} / \mathrm{mmol}$ (DQ $\beta$ probe) or $110 \mathrm{TBq} / \mathrm{mmol}$ (IVS 1 probe).

Construction of a series of progressive deletions for sequencing. The BamHI 3.7-kb genomic insert was subcloned in the BamHI site of pUC19 (28). This construct was then linearized with the restriction enzymes Sph 1 and HindII. Sph1 digestion between the BamHI site in pUC19 and the attachment site for the reverse-sequencing primer (Amersham International) was carried out to leave a four-base $3^{\prime}$ overhang, which is inaccessible to Exonuclease III (29) (Pharmacia PL Biochemicals, Uppsala, Sweden). HindII digestion within the polylinker sequence of pUC19, between the Sph1 site and the BamHI cloning site, was used to generate a blunt end, susceptible to Exonuclease III. There were no sites for Sph1 and HindII in the insert. Unidirectional deletions, ranging from the primer attachment site in pUC19 to various points within the insert, were isolated by digestion of the plasmid DNA with Sph1 and HindII, followed by phenol/chloroform extraction and ethanol precipitation. The linearized plasmid DNA was resuspended to $0.1 \mathrm{~g} /$ liter in $6.6 \mathrm{mM}$ Tris-HCl $\mathrm{pH}$ 7.4) containing $6.6 \mathrm{mM} \mathrm{MgCl}_{2}$ and ncubated at $37^{\circ} \mathrm{C}$ for $5 \mathrm{~min}$ before Exonuclease III was added to a final concentration of $10 \mathrm{U} / \mu$. In 15-s intervals, $3510-\mu \mathrm{l}$ aliquots were transferred to $30 \mu \mathrm{l}$ of $0.2 \mathrm{M} \mathrm{NaCl}$ containing $5 \mathrm{mM}$ EDTA and heated to $70^{\circ} \mathrm{C}$ for $10 \mathrm{~min}$ to inactivate the enzyme. The DNA was precipitated by the addition of $120 \mu \mathrm{l}$ of ethanol and centrifuged and each pellet was resuspended in $80 \mu \mathrm{l}$ of 0.05 $\mathrm{M} \mathrm{NaOAc}$ (pH 4.5) containing $0.1 \mathrm{M} \mathrm{NaCl}, 30 \mathrm{mM} \mathrm{ZnSO}_{4}$, and 75 Vogt $\mathrm{U} / \mathrm{ml}$ S1 nuclease (Boehringer) to remove by incubation for 30 min at room temperature the single-stranded 3 '- and 5'-end protutions generated by Sphl and Exonuclease III, respectively. The reaction was terminated by phenol/chloroform extraction followed by ethanol precipitation. The pellets were resuspended in $10 \mu \mathrm{l} 25 \mathrm{mM}$ Tris- $\mathrm{HCl}(\mathrm{pH}$ 7.4) containing $5 \mathrm{mM} \mathrm{MgCl}, 5 \mathrm{mM}$ dithiothreitol (DTT), $0.25 \mathrm{mM}$ spermidine, $1 \mathrm{mM}$ ATP, $10 \mu \mathrm{g} / \mathrm{ml} \mathrm{BSA}$, and $700 \mathrm{U} / \mathrm{ml}$ T4 DNA ligase (Amersham), and ligated at room temperature overnight. E. coli KM109 was transformed with $5 \mu \mathrm{l}$ of each of the ligated fractions according to Hanahan (30) and the bacterial cells spread on L-broth plates containing $50 \mu \mathrm{g} / \mathrm{ml}$ ampicillin. About 10-20 transformants from each aliquot were selected for characterization of deletion size by agarose gel electrophoresis. Each clone was grown overnight in a 5-ml L-broth culture in the presence of $50 \mu \mathrm{g} / \mathrm{ml}$ ampicillin. Small-scale plasmid preparations were made by the alkaline lysis method (31), with the following modifications. After precipitation with potassium acetate, supernatants were centrifuged for $2 \mathrm{~min}$, transferred to fresh tubes containing $0.6 \mathrm{vol}$ of isopropanol, and centrifuged for $5 \mathrm{~min}$ at $4^{\circ} \mathrm{C}$. The pellets were washed with $80 \%$ ethanol and resuspended in Tris-EDTA buffer. An equal volume of $4 \mathrm{M} \mathrm{LiCl}$ was added. After $5 \mathrm{~min}$ at $0^{\circ} \mathrm{C}$, the precipitates were collected by centrifugation for $2 \mathrm{~min}$. The supernatants were incubated for $30 \mathrm{~min}$ at $37^{\circ} \mathrm{C}$ with $25 \mu \mathrm{g} / \mathrm{ml} \mathrm{RNase} \mathrm{A}$, followed by phenol/chloroform extraction. The plasmid DNA was then precipitated by incubating the samples for $10 \mathrm{~min}$ at $0^{\circ} \mathrm{C}$ in $2.5 \mathrm{vol}$ of ethanol. After centrifugation, pellets were 
washed once each in $80 \%$ and $99 \%$ ethanol, air dried, and resuspended in Tris-EDTA buffer. The deletion breakpoints were estimated by agarose gel electrophoresis of appropriate restriction digest of the plasmid DNA. This analysis made it possible to decide which clones should be further characterized by sequencing.

Sequencing. Selected clones from the preparations described above were sequenced by the chain termination method, using double-stranded, supercoiled plasmid DNA (32). Most clones from each aliquot had deletion breakpoints positioned within a range of 50-100 bp. The distance between fractions was roughly $100-200 \mathrm{bp}$.

Statistical evaluation. The difference in frequency between control and test samples was estimated by the Fisher exact test or the $\chi^{2}$ test with Yate's correction. The level of significance was accepted to be $P$
$<0.05$ after the $P$ value was corrected for the number of variable fragments observed between individuals. The relative risk $(R R)$ was calculated from the formula: $R R=$ (positive patients $\times$ negative controls)/(negative patients $\times$ positive controls), and the absolute relative risk (ARR) from ARR $=$ (positive patients $\times$ total controls) $/($ positive controls $\times$ total patients) $\times$ prevalence of IDDM. The prevalence of IDDM in Denmark was $0.38 \%(25)$.

\section{Results}

Sequence of the polymorphic BamHI 3.7-kb fragment. The entire nucleotide sequence of the cloned 3.7-kb fragment from an HLA-

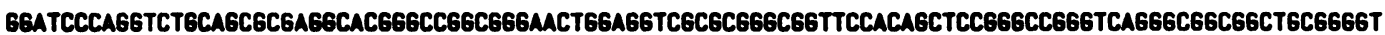

100

Asp Phe Val Tyr Gln Phe Lys Ala Mat Cys Tyr

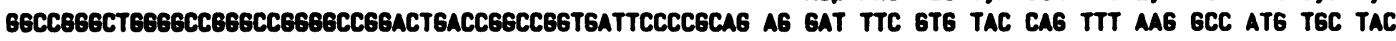

Phe Thr Aen 6ly Thr blu arg Val Ang Tyr Val Thr Arg Tyr Ile Tyr Asn Arg 6lu 6lu Tyr Ala Arg Phe Asp Ser

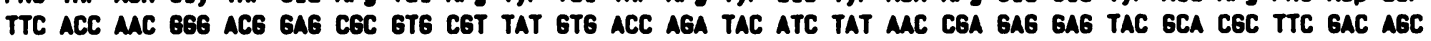

Asp Val Glu Val Tyr Arg Ale Val Thr Pro Leu 6ly Pro Pro Asp Ala Glu Tyr Trp Aen Ser gln Lys glu Val Leu

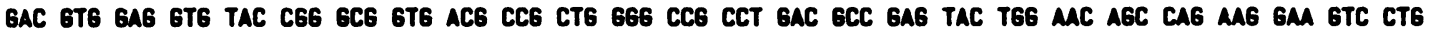

Glu arg Thr Arg Alo Glu Leu Aap Thr Val Cys arg His Aan Tyr Gin Leu glu Leu arg Thr Thr Leu $61 n$ Arg arg gag agg acc ceg geg gag tTg gac ace gtg tgC aga cac aac tac cag tTg gag ctc cec acg acc tTg cag age cea $\checkmark$

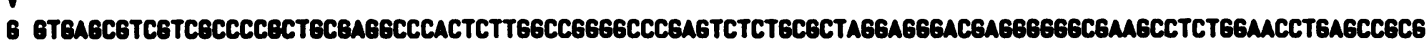

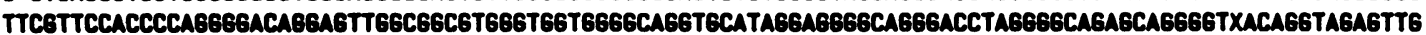

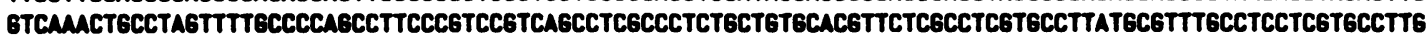

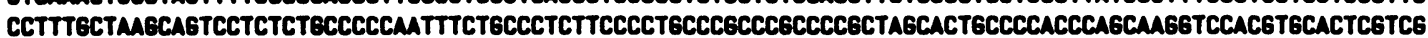

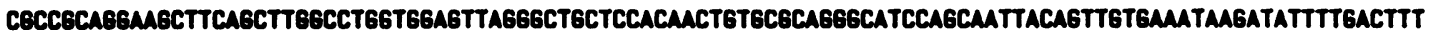

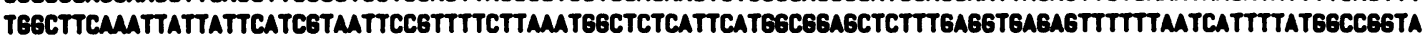

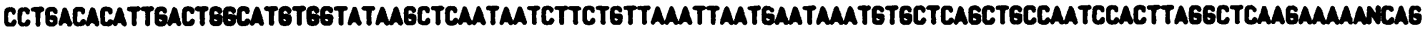

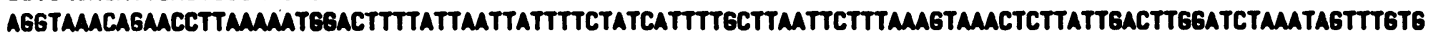

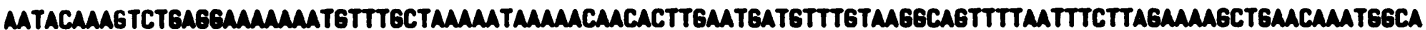

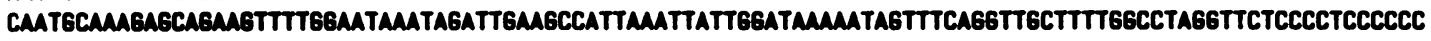

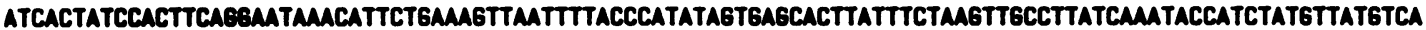

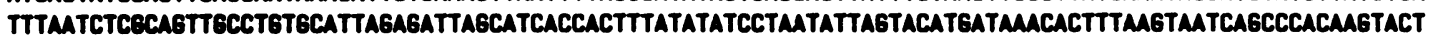

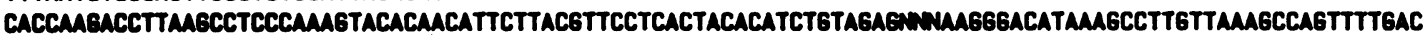

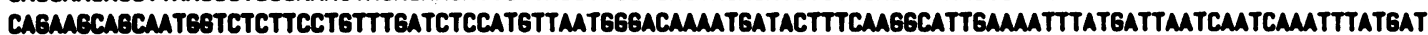

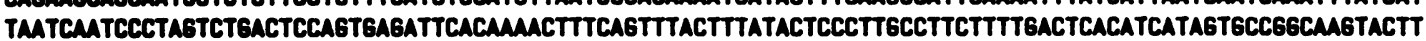

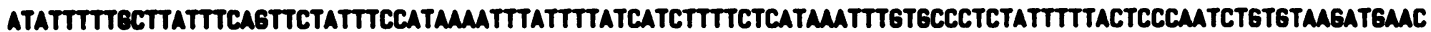

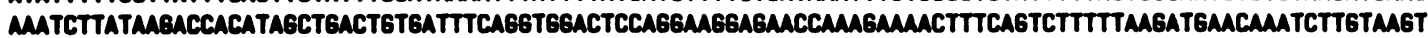

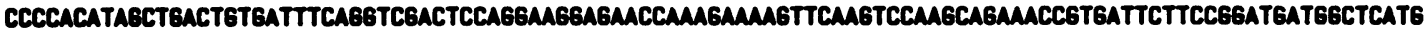

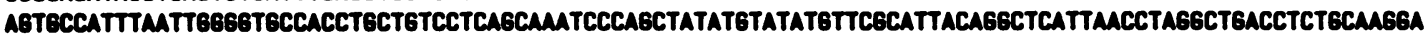

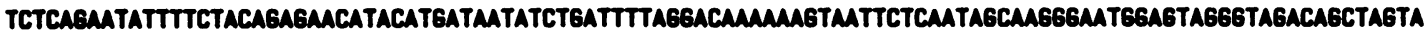

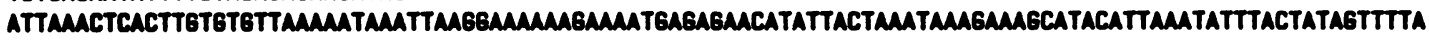

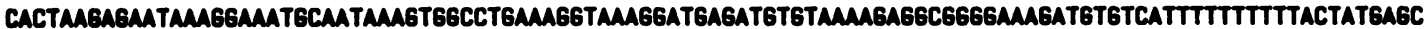

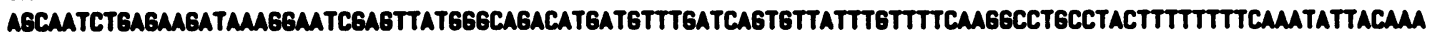

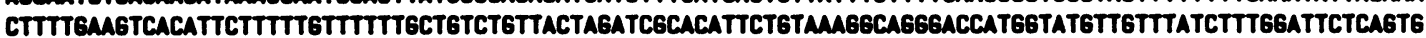

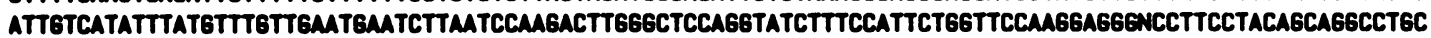

al Glu Pro Thr Val Thr Ile Ser Pro Ser Arg Thr

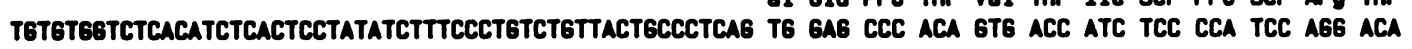

Glu Ale Leu Aen His His aen Leu Leu Val Cys Sar Val Thr Asp Phe Tyr Pro Ala $61 n$ Ile Lys Val Arg Tro Phe

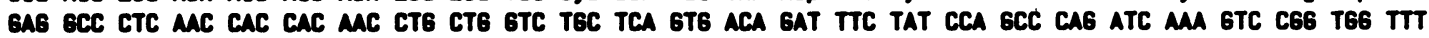

Arg Aen Aap Gln 61 blu Thr Thr 6ly Val Val Ser Thr Pro Leu Ile arg Asn 6ly Asp Trp Thr Phe 6ln Ile Leu

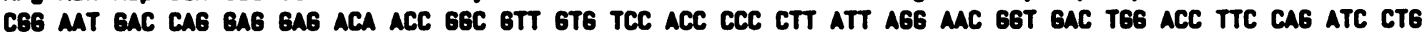

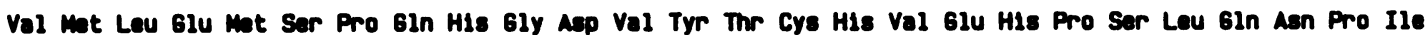

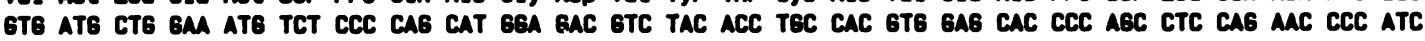

Thr Val Glu Trp

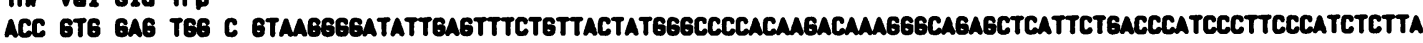

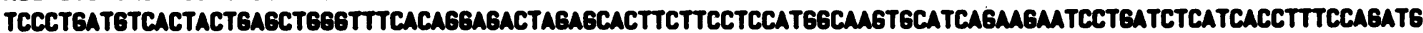
CTAGEGAMATTACTCTACATACTETTTCTCTEQATCC

Figure 2. The nucleotide sequence of the cloned BamHI 3.7-kb DNA endonuclease fragment from an HLA-DR4-containing chromosome of a healthy individual. 
Table I. Sequence Comparison between $D Q \beta 3.7$ and Published $H L A-D Q \beta$-Chain Sequences

\begin{tabular}{llll}
\hline $\begin{array}{l}\text { Sequence of } \\
\text { DQ } \beta \text { 3.7 }\end{array}$ & Comparison & Nucleotides & $\begin{array}{l}\text { Amino } \\
\text { acids }\end{array}$ \\
\hline IVS 1 & Cos II-102 & 94 & - \\
& DC3 $\beta$ & 91 & - \\
$\beta_{1}$ exon & $\operatorname{cos~II-102~}$ & 98 & 96 \\
& DC3 $\beta$ & 91 & 80 \\
& pII- $\beta-1$ & 90 & 80 \\
& pII- $\beta-2$ & 88 & 78 \\
& DC1 $\beta$ & - & 85 \\
$\beta_{2}$ exon & KT3c21 & 91 & 85 \\
& $\cos$ II-102 & 98 & 97 \\
& DC3 $\beta$ & 98 & 96 \\
& pII- $\beta-1$ & 96 & 96 \\
IVS 3 & pII- $\beta-2$ & 97 & - \\
& $\cos$ II-102 & 96 & - \\
& DC3 $\beta$ & 96 & \\
\hline
\end{tabular}

Comparison of nucleotide and amino acid sequences of the Bam 3.7kb fragment (DR4 haplotype) with the IVS 1 , coding regions for the first domain ( $\beta_{1}$ exon), second domain ( $\beta_{2}$ exon), and the IVS 3 of

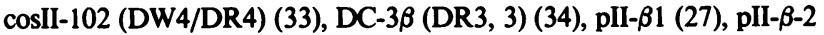
(35) (DR3, 6), DC1 $\beta$ (DR2, 2) (36), and KT3c21 (DR 4, 4) (37).

DR4-containing chromosome showed the fragment, to which we refer as $\mathrm{DQ} \beta 3$ 3.7, to be 3,558 bp in length (Fig. 2). Comparing this sequence (Table I) to previously published HLA-DR and DQ $\beta$-chain genes $(27,33-37)$ allowed us to identify two coding regions that were nearly identical to the cosmid clone $\cos$ II- 102 HLA-DQ $\beta$-chain gene (33). The coding regions of the first and second domains showed $88 \%-98 \%$ homology to other HLA-DQ $\beta$-chain genes. The $154 \mathrm{bp}$ of the first intervening sequence (IVS 1) and the $225 \mathrm{bp}$ from the third (IVS 3 ) also compare favorably $(91 \%-96 \%)$ to the cos II-102 (33) and DC3 $\beta$ (34) HLA-DQ $\beta$ chain genes (Table I). All four splice junctions conformed with the GT/AG rule described in Breatnach and Chambon (38).

The predicted amino acid sequence (Figs. 2 and 3 ) in the second exon coding for part of the $\mathrm{NH}_{2}$-terminal end and the $\beta 1$ domain of the protein showed only four amino acids in positions 13, 26, 45, and 57 (Fig. 3) to differ from the cos II-102 (33), whereas there were 11 amino acid substitutions compared with the other HLA-DR-associated DQ $\beta$-chain sequence deduced from the KT3c21 cDNA clone (37). It is noted that the amino acid substitutions in different HLA-DQ $\beta$-chains primarily occur in positions $25-60$ and $65-80$ (Fig. 3). In contrast, only two amino acid substitutions between $\mathrm{DQ} \beta 3.7$ and $\cos$ II-102 were found in the second domain (Fig. 3). It was concluded, therefore, that the BamHI 3.7-kb fragment represents an HLADQ $\beta$-chain gene, and that the two BamHI sites defining the fragment were located in the first and third intervening sequences, respectively (Fig. 4).

The IVS 1 probe detects differences between $H L A-D R 3 / 4$ healthy and IDDM individuals. A probe was constructed from the cloned $\mathrm{DQ}_{\beta} 3.7$ fragment (Fig. 4). This short (166-bp) IVS 1 probe was expected to hybridize only to closely related DQ/ DX-related $\beta$-chain genes. Furthermore, because the IVS 1 probe primarily represents noncoding sequences, which may be less conserved than their coding counterparts, we assumed little crosshybridization to alleles of different genes and loci. We first tested 30 HLA-DR $3 / 4^{+}$Danish individuals (Table II), 13 of them were IDDM patients and 17 were healthy controls, to find a simple hybridization pattern (Fig. 5) of only five fragments being 12, 10,4 , and 3.7 and $3.2 \mathrm{~kb}$ (Table II). The 10-kb fragment was present among all individuals and all (13 of 13) IDDM patients had the 12-kb fragment compared with 10 of $17(59 \%)$ of controls $(P<0.02)$. In fact, all IDDM patients were $12-$ and $4-\mathrm{kb}$ positive although four different restriction enzyme patterns were found among the controls (Table II).

Association between IDDM and the IVS 1 probe restriction fragments in a population study. The simplified restriction pattern and the likelihood that we were probing a limited number of DQ/DX-related $\beta$-chain genes made it possible to test whether the IVS 1 probe would resolve differences between randomly selected IDDM patients and healthy individuals. Such a study would allow an analysis of the strength of a possible association between IDDM and the HLA-DQ locus. It was also important to establish whether the IVS 1 probe would reveal a simple hybridization pattern in the background population to permit studies on the relative risk of developing diabetes without previous knowledge of HLA types. Therefore, we compared 177 healthy, adult blood donors (controls) with 113 IDDM patients.

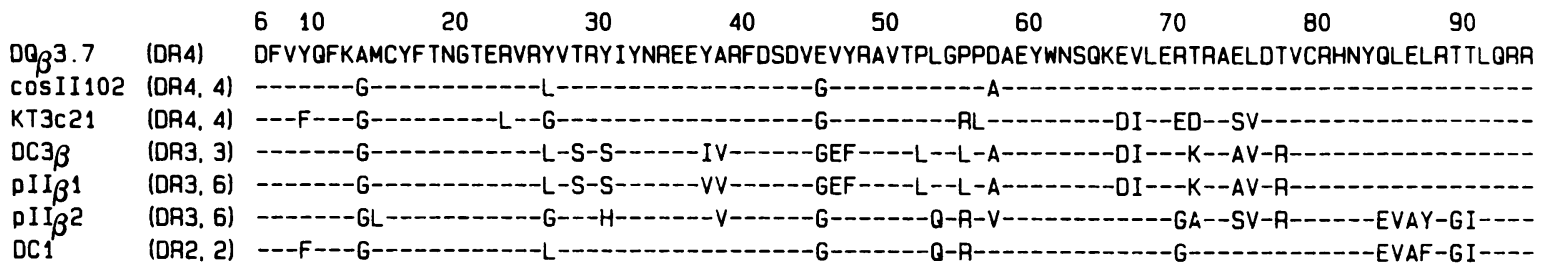

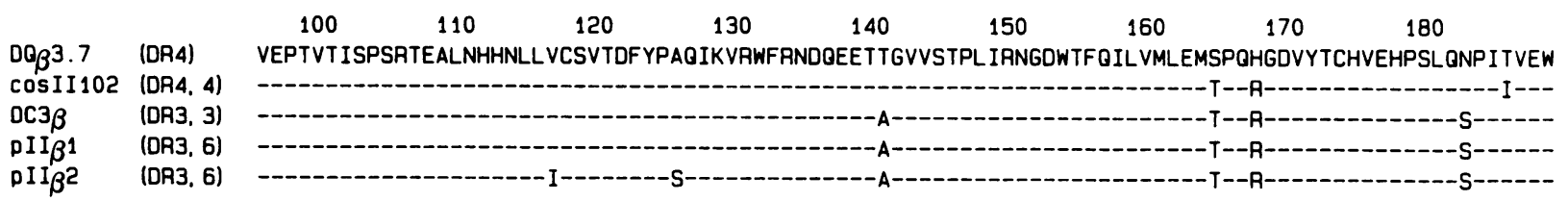

Figure 3. Comparison between the deduced amino acid sequence of the DQ 3.7 fragment with published HLA-DQ $\beta$-chain sequences. See Table I for reference to previously published sequences. 


\section{HLA - DQ gene}

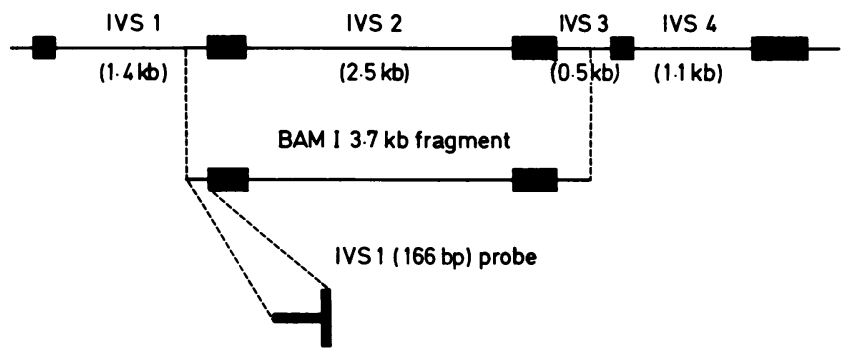

Figure 4. An HLA-DQ $\beta$-chain gene and the localization of the BamHI 3.7-kb fragment detected by DNA-DNA hybridization using an HLA-DQ $\beta$-chain CDNA probe. The genomic probe, IVS 1 probe, representing $154 \mathrm{bp}$ of the first intervening sequence and $12 \mathrm{bp}$ of the $\beta_{1}$-domain coding sequence, is indicated.

The presence of distinct hybridization signals were seen in all individuals (Fig. 5) to yield a single nonpolymorphic fragment of $10 \mathrm{~kb}$ and only six variable fragments. Among the 113 IDDM patients and including the 10-kb fragment, $25(21 \%), 76(65 \%)$ $(P<0.001)$, and $16(14 \%)(P<0.001)$ had two, three, or four restriction fragments, respectively, compared with 25 (14\%), 79 (45\%), and 71 (40\%) among the controls. Only two controls had as many as five and six fragments, respectively. Analysis of the frequency of individual fragments among IDDM patients and controls revealed additional differences (Table III). Correcting the $P$ values for the number of variable fragments observed, it was demonstrated that the $12-\mathrm{kb}\left(P<10^{-4}\right)$ and 4-kb $\left(P<10^{-4}\right)$ fragments were increased among the IDDM patients whereas the 7.5-kb $\left(P<10^{-4}\right)$ and $3.7 \mathrm{~kb}\left(P<10^{-3}\right)$ fragments were decreased. As many as 108 of $113(92 \%)$ of the IDDM patients had the 12- and/or the 4-kb fragment compared with 112 of 177 (63\%) of the controls $\left(P<10^{-4}\right)$ (Table IV). The simultaneous
Table II. RFLP after BamHI Digestion

\begin{tabular}{llll}
\hline & \multicolumn{2}{l}{ Prevalence among } & \\
\cline { 2 - 3 } $\begin{array}{l}\text { Restriction } \\
\text { fragment size }\end{array}$ & $\begin{array}{l}\text { IDDM } \\
(n=13)\end{array}$ & $\begin{array}{l}\text { Controls } \\
(n=17)\end{array}$ & $P$ value \\
\hline$k b$ & $n(\%)$ & $n(\%)$ & \\
$12-4$ & $13(100)$ & $9(53)$ & 0.02 \\
$12-4-3.2$ & 0 & $1(6)$ & NS \\
$4-3.7$ & 0 & $6(35)$ & NS \\
4 & 0 & $1(6)$ & NS \\
\hline
\end{tabular}

Detection of RFLP was done with the HLA-DQ $\beta$-chain gene IVS 1 probe in HLA-DR3/4-identical IDDM and control individuals. $P$ values corrected for number of variable fragment patterns.

presence of the 12- and 4-kb fragments was found among 40 of $113(34 \%)$ IDDM compared with 17 of 177 (10\%) control individuals $\left(P<10^{-4}\right)$. There were no differences between sex in the frequency distribution of the different fragments.

We analyzed the frequency of the different fragments in relation to age at onset (Fig. 1, Table IV). Among the 43 IDDM patients with age at onset below $20 \mathrm{yr}, 42(98 \%)$ were 12- and/ or 4-kb positive compared with 112 of $177(63 \%)$ of the controls $\left(P<10^{-4}\right)$. The 12-4-kb-positive individuals amounted to 24 (56\%), found only among 17 of $177(10 \%)$ controls $\left(P<10^{-4}\right)$. The relative risk for a young 12-4-kb-positive individual to develop IDDM amounts, therefore, to 91.8 compared with the control individuals who are negative for both of these fragments. The absolute relative risk was $2.2 \%$.

The presence or absence of the 12-kb and/or 4-kb fragments were also analyzed in a group of 46 patients with NIDDM (Table IV). Neither individual fragments nor the fragment combinations a

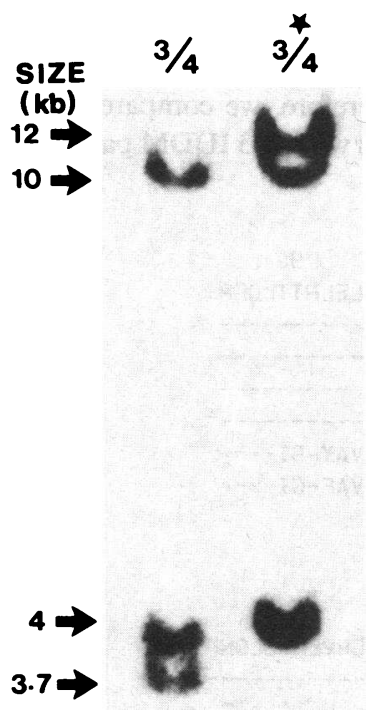

b

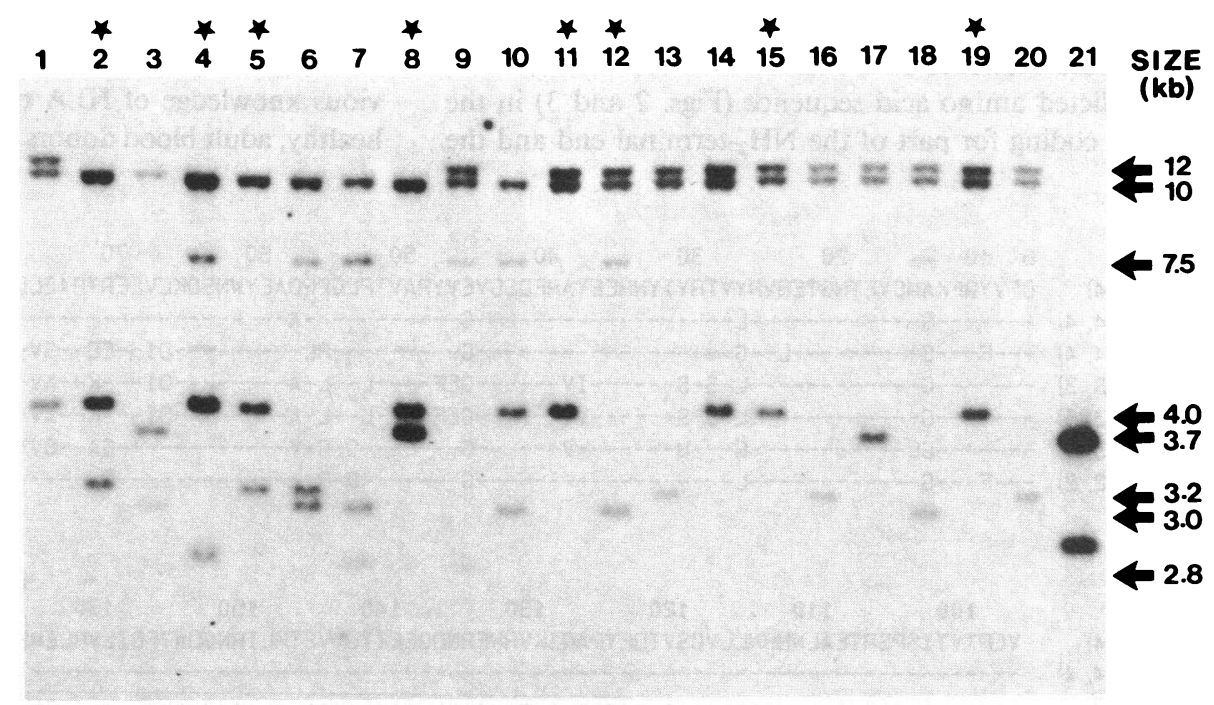

Figure 5. (a) RFLP in HLA-DR3/4 healthy and IDDM (star) individuals detected with the HLA-DQ $\beta$-chain IVS 1 probe. (b) RFLP detected with the HLA-DQ $\beta$-chain IVS-1 gene probe after BamHI digestion of blood mononuclear cell DNA from 19 randomly selected blood donors and IDDM patients (star). Lane 1 is DNA from a lymphoblastoid cell line of an HLA-DR3/4 IDDM patient and lane 21 is the plasmid DNA containing the cloned BamHI 3.7-kb fragment. 
Table III. Frequency of Restriction Fragments after BamHI Digestion and Hybridization with the HLA-DQ IVS 1 Probe in IDDM, NIDDM, and Control Individuals

\begin{tabular}{|c|c|c|c|c|c|c|c|c|}
\hline Fragment size & $\begin{array}{l}\text { Controls } \\
(n=177)\end{array}$ & $\begin{array}{l}\text { IDDM } \\
(n=113)\end{array}$ & $P$ value & $\mathbf{R} \mathbf{R}$ & ARR & $\begin{array}{l}\text { NIDDM } \\
(n=46)\end{array}$ & $\begin{array}{l}P \text { value } \\
\text { vs. controls }\end{array}$ & $\begin{array}{l}P \text { value } \\
\text { vs. IDDM }\end{array}$ \\
\hline$k b$ & $n(\%)$ & $n(\%)$ & & & $\%$ & $n(\%)$ & & \\
\hline 12 & $65(37)$ & $73(65)$ & $10^{-4}$ & 3.1 & 0.7 & $19(42)$ & NS & 0.03 \\
\hline 10 & $117(100)$ & $112(99)$ & NS & & 0.4 & $46(100)$ & NS & NS \\
\hline 7.5 & $89(50)$ & $21(19)$ & $10^{-4}$ & 0.2 & 0.1 & $23(50)$ & NS & $10^{-3}$ \\
\hline 4 & $64(36)$ & $71(63)$ & $10^{-4}$ & 3.0 & 0.7 & $17(37)$ & NS & 0.01 \\
\hline 3.6 & $52(29)$ & $13(12)$ & $10^{-3}$ & 0.3 & 0.2 & $7(15)$ & NS & NS \\
\hline 3.2 & $52(29)$ & $20(18)$ & NS & 0.5 & 0.2 & $17(37)$ & NS & 0.04 \\
\hline 3.0 & $65(37)$ & $7(7)$ & $10^{-3}$ & & 0.1 & $13(28)$ & NS & 0.002 \\
\hline 2.8 & $19(11)$ & $11(10)$ & NS & 0.9 & 0.4 & $13(28)$ & NS & 0.02 \\
\hline
\end{tabular}

All $P$ values are corrected for the number of variable fragments. ARR, absolute relative risk; RR, relative risk.

of 12 and $4 \mathrm{~kb}$ differed in frequency between the NIDDM and the control individuals. We noted the absence of both the 12 and 4-kb fragments was 7 of $70(10 \%)$ among the IDDM patients with age at onset older than 20 yr compared with 17 of $46(37 \%)$ of NIDDM patients $\left(P<10^{-4}\right)$.

In our current family study (in preparation), we found a family with an IDDM proband who was HLA-DR3/4 and 12 $\mathrm{kb}$ positive. HLA-DR typing alone was not informative because the mother was DR3/4 and IVS-1 12-, 7.5-, and 3.0-kb positive and the father, DR3, IVS $14-\mathrm{kb}$ positive. However, the analysis of their five children demonstrated that the father's DR3 was associated with a 4-kb fragment on both chromosomes while the mother's DR3-containing chromosome had the IVS 1 fragments 7.5-3.0 kb. The analysis in Table III shows that these two fragments were decreased in frequency among the IDDM patients. The IVS 1 probe therefore appears to resolve the HLADR3 haplotype into subtypes of greater or lower propensity to develop IDDM. Further, in our family analysis, we have also identified one IDDM patient who is HLA-DR -/7 but was found to have the BamHI IVS 1 probe 4-kb fragment associated with his HLA-DR blank allele (data not shown).

\section{Discussion}

The present study, which to our knowledge is the first report of a successful cloning of a disease-associated RFLP fragment detected by an HLA-D-region cDNA probe, allows two major conclusions: ( $a$ ) by sequencing the cloned polymorphic BamHI $3.7-\mathrm{kb}$ fragment $(16,17)$, we establish that this polymorphism is due to a structural difference in an HLA-DQ $\beta$-chain gene; (b) by using the IVS 1 probe; we establish that BamHI 3.7-kb fragment-negative IDDM patients are BamHI 12-kb fragment positive. The less complex restriction pattern of the HLA-DQ $\beta$-chain IVS 1 probe (Fig. 5) then allowed us, in our family study (in preparation), to show that not only HLA-DR4-but also HLADR3-containing chromosomes may differ between controls and IDDM patients. Finally, in one HLA-DR -/7 IDDM individual, the IVS 1 probe detected a 4-kb fragment. Therefore, these data

Table IV. Frequency of the 12 and 4-kb BamHI Restriction Fragments Detected after Hybridization with the HLA-DQ IVS 1 Probe in Patients with IDDM Dependent on Age at Onset, NIDDM, and in Control Individuals

\begin{tabular}{|c|c|c|c|c|c|c|}
\hline & \multirow[b]{2}{*}{$n$} & \multicolumn{5}{|c|}{ Fragment size $(k b)$} \\
\hline & & 12 & 4 & $12-4$ & 12 and/or 4 & Neither 12 nor 4 \\
\hline Controls & 177 & $65(37 \%)$ & $64(36 \%)$ & $17(10 \%)$ & $112(63 \%)$ & $65(37 \%)$ \\
\hline IDDM, onset below $20 \mathrm{yr}$ of age & 43 & $32(74 \%)$ & $34(79 \%)$ & $24(56 \%)$ & $42(98 \%)$ & $1(2 \%)$ \\
\hline$P$ value & & $10^{-4}$ & $10^{-4}$ & $10^{-4}$ & $10^{-4}$ & $10^{-4}$ \\
\hline $\mathbf{R R}$ & & 5.0 & 6.7 & 11.9 & 24.4 & 0.04 \\
\hline $\mathbf{R R}^{*}$ & & - & - & 91.8 & - & - \\
\hline ARR & & $0.8 \%$ & $0.8 \%$ & $2.2 \%$ & $0.6 \%$ & $0.02 \%$ \\
\hline IDDM, onset above $20 \mathrm{yr}$ of age & 70 & $41(59 \%)$ & $37(53 \%)$ & $15(21 \%)$ & $63(90 \%)$ & $7(10 \%)$ \\
\hline$P$ value & & 0.002 & 0.02 & 0.01 & $10^{-4}$ & $10^{-4}$ \\
\hline $\mathbf{R R}$ & & 2.4 & 1.4 & 2.6 & 5.2 & 0.19 \\
\hline $\mathbf{R R}^{*}$ & - & - & - & 8.2 & - & - \\
\hline ARR & & $0.6 \%$ & $0.6 \%$ & $0.8 \%$ & $0.5 \%$ & $0.3 \%$ \\
\hline NIDDM & 46 & $19(42 \%)$ & $17(37 \%)$ & $6(13 \%)$ & $29(63 \%)$ & $17(37 \%)$ \\
\hline$P$ value & & NS & NS & NS & NS & NS \\
\hline
\end{tabular}

ARR, absolute relative risk; $R R$, relative risk. * $R R$ is relative risk compared with controls with neither the 12- nor the 4-kb fragments. 
strongly suggest that an IDDM susceptibility gene would seem closer to HLA-DQ than HLA-DR. Comparing the RFLP patterns obtained with CDNA probes for HLA-DR and HLA-DQ $\beta$-chains, Böhme et al. (24) have recently reached the same conclusion. Because the HLA-DQ RFLP patterns do not conform with currently available serologic reagents $(21,23,24)$, our approach of using the IVS 1 probe to analyze IDDM and control individuals, without previous knowledge of their HLA types, is an acceptable approach. It also means that the relative risk estimates will not be comparable to those obtained by serologic typing, in that all individuals will show a RFLP fragment pattern whereas $\sim 20 \%$ of the background population are assigned as blanks, owing to the lack of suitable HLA-DR typing sera. Several recent investigations, using methods for serology, primed lymphocyte typing, biochemical analysis, and restriction fragment length polymorphism, have described several subtypes of HLADR4 (21, 23, 24, 39-41). Combining all four techniques to analyze DR $4^{+}$homozygous cells, the presence of at least nine different haplotypes of HLA-DR4 $(42,43)$ was revealed. The difference in HLA-DR4 haplotypes may explain the controversy $(12,13)$ over whether IDDM is associated with the DR rather than with the DW locus.

The IVS 1 probe seems to be specific for the HLA-DQ/DX locus because we found only one to three variable fragments per individual. The nonpolymorphic $10-\mathrm{kb}$ fragment presumably represents the HLA-DX $\beta$-chain gene. We note that the 7.5-, $3.0-$, and the 2.8-kb fragments never occur alone, and that the 3.0-kb always appears together with the $7.5-\mathrm{kb}$ fragment. Some of these fragments may therefore occur in the same haplotype.

The high relative risk value of 91.8 for the simultaneous presence of the 12- and 4-kb fragments (Table IV) may be due to the ability of the IVS 1 probe to differentiate between subtypes of both HLA-DR4 and DR3. Because the 166-bp IVS sequence was most closely related to previously described DQ $\beta$-chain gene sequences $(27,33-37)$, we argue that, the DQ $\beta$-chain gene either represents a diabetes-susceptibility gene or is closer to a putative susceptibility gene than the HLA-DR locus. This would be particularly true for individuals developing IDDM below the age of $20 \mathrm{yr}$ (Table IV). This conclusion is supported by the recent observation that the HLA-DQ-specific monoclonal antibody, TA 10 (42), differentiates between HLA-DR4 identical IDDM and control individuals (Tait, personal communication).

We compared the intervening sequences of our BamHI 3.7$\mathrm{kb}$ fragment with the two published $\mathrm{DQ}$ intervening sequences which are associated with HLA-DR4 (cos II-102) (33) and HLADR3 (DC3 ) (34), respectively. Because the DC3 $\beta$ was cloned from a DR3/3 homozygous cell line, we would predict the presence of a BamHI fragment of $\sim 4 \mathrm{~kb}$ rather than $3.6 \mathrm{~kb}$. However, both BamHI restriction sites in the IVS 1 and IVS 3 (Fig. 2) were preserved in the DC3 $\beta$ sequence (34). Therefore, when analyzing the IVS 2 sequence of $\cos$ II- 102 with that of DC3 $\beta$ we found that the latter was $300 \mathrm{bp}$ larger, because of the insertion of an Alu sequence which was not reported by the authors (34). It is important to note that the DQ $3.7-\mathrm{kb}$ fragment had no sequences corresponding to the Alu sequence of the DC3 $\beta$. Furthermore, plasmid DNA, containing the DQ 3.7 fragment, did not hybridize with the Alu-sequence probe BLUR 2 (44) (data not shown). Therefore, RFLP associated to the development of IDDM, or other diseases associated to HLA, may be linked not only to the absence or presence of certain restriction enzyme sites but to insertion of sequences as well.
The two BamHI restriction sites in the IVS 1 and IVS 3 of the DQ 3.7-kb fragment (Fig. 1) are missing in the cos II-102 (33). The restriction enzyme map of this cosmid clone suggests that the IVS 1 probe sequence is contained within a BamHI fragment that is larger than $6 \mathrm{~kb}$. Because cos II- 102 is from an HLA-DR4 ${ }^{+}$individual, its DQ $\beta$-chain gene may contain a BamHI 12-kb fragment. The BamHI 3.7-kb polymorphism would therefore be caused by either point mutations or the presence of unknown inserted sequences within noncoding regions. However, even though these events have occurred in noncoding sequences, it is notable that all three alleles of the HLA-DQ $\beta$ chain gene also differ in their coding regions (Fig. 3).

Our further studies involve cloning and sequencing of the 12- and 4-kb fragments from IDDM patients. This is important, because these two approaches will not only give further structural information on the HLA-DQ $\beta$-chain genes but also allow us to derive yet other probes from IDDM patients and permit further dissection of disease susceptibility, both in population and family studies. Sequence information should also resolve whether the 12-kb fragment on HLA-DR4-containing chromosomes is related to the HLA-DR2-associated BamHI 12-kb fragment found to be positively associated with multiple sclerosis (18).

Our approach in cloning RFLP fragments should eventually lead to the identification of an HLA-D locus gene that gives maximal susceptibility to develop IDDM. It has been previously shown that HLA-DR3 and 4 have different regulatory functions on the proliferative $\mathrm{T}$ lymphocyte response to mumps and coxsackie B4 (45), two viruses implicated in the etiology of IDDM (4). Class II antigens confer restriction in antigen presentation perhaps by direct binding of processed antigen (46). Isolation and structural analysis of these HLA-D class II molecules will therefore be of central importance in testing the hypothesis $(2,47,48)$ that the pathogenesis of IDDM is conferred by the ability of these molecules to present antigens that induce an abnormal immune response against the pancreatic $\beta$ cells.

\section{Acknowledgments}

We wish to thank Lissi Aagard for expert technical assistance, A. Svejgaard and F. Kissmeyer-Nielsen for the supply of white blood cells from HLA$\mathrm{DR} 3 / 4^{+}$individuals, and our colleagues for many useful discussions and suggestions.

Birgitte Michelsen is supported by a fellowship from the Juvenile Diabetes Foundation International. The Hagedorn Research Laboratory together with the Steno Memorial Hospital is a World Health Organization Collaborating Center for Research and Training in the Pathogenesis of Diabetes Mellitus and is supported by the foundation Nordisk Insulinlaboratorium.

\section{References}

1. Cahill, G. F., and H. O. McDevitt. 1981. Insulin-dependent diabetes mellitus: the initial lesion. N. Engl. J. Med. 304:1454-1465.

2. Scott, J., J. Nerup, and Å. Lernmark. 1985. Immunologic factors in diabetes mellitus. In Clinical Immunology Update. W. F. Rosse, editor. Elsevier Science Publishing Co., Inc., New York. 53-85.

3. Rossini, A. A., J. P. Mordes, and A. A. Like. 1985. Immunology of insulin-dependent diabetes mellitus. Annu. Rev. Immunol. 3:289-320.

4. Yoon, J. W., M. Austin, T. Onodera, and A. L. Notkins. 1979. Virus-induced diabetes mellitus. N. Engl. J. Med. 300:1173-1179. 
5. Gepts, W. 1965. Pathologic anatomy of the pancreas in juvenile diabetes mellitus. Diabetes. 14:619-633.

6. Foulis, A. K., and J. A. Stewart. 1984. The pancreas in recentonset type 1 (insulin-dependent) diabetes mellitus: insulin content of islets, insulitis and associated changes in exocrine acinar tissue. Diabetologia. 26:456-461.

7. MacCuish, A. C., and W. J. Irvine. 1975. Autoimmunological aspects of diabetes mellitus. Clin. Endocrinol. Metab. 4:435-471.

8. Gorsuch, A. N., K. M. Spencer, J. Lister, J. M. McNally, B. M. Dean, G. F. Bottazzo, and A. G. Cudworth. 1981. The natural history of type I (insulin-dependent) diabetes mellitus: evidence for a long prediabetic period. Lancet. ii:1363-1365.

9. Srikanta, S., O. Gunda, G. Eisenbarth, and J. S. Soeldner. 1983. Islet cell antibodies and beta cell function in monozygetic triplets and twins initially discordant for type 1 diabetes mellitus. N. Engl. J. Med. 308:322-325.

10. Bækkeskov, S., J. H. Nielsen, B. Marner, T. Bilde, J. Ludvigsson, and $\AA$. Lernmark. 1982. Autoantibodies in newly diagnosed diabetic children immunoprecipitate specific human pancreatic islet cell protein. Nature (Lond.). 298:167-169.

11. Hägglöf, B., A. Rabinovitch, P. Mackay, A. Huen, A. H. Rubenstein, B. Marner, J. Nerup, and Å. Lernmark. 1986. Islet cell and other organ-specific autoantibodies are increased among healthy first-degree relatives to insulin-dependent diabetic children. Acta Padiatr. Scand. 75:1-8.

12. Platz, P., B. K. Jakobsen, M. Morling, L. P. Ryder, A. Svejgaard, M. Thomsen, M. Christy, H. Kromann, J. Been, J. Nerup, and A. Green. 1982. A genetic analysis of insulin-dependent diabetes mellitus. Diabetologia. 21:108-115.

13. Wolf, E., K. M. Spencer, and A. G. Cudworth. 1983. The genetic susceptibility to type I (insulin-dependent) diabetes: analysis of the HLADR association. Diabetologia. 24:224-230.

14. Johnston, C., D. A. Pyke, A. G. Cudworth, and E. Wolf. 1983. HLA-DR typing in identical twins with insulin-dependent diabetes: difference between concordant and discordant pairs. Br. Med. J. 286:253255.

15. Dahlquist, G., L. G. Blom, G. Holmgren, B. Hägglöf, Y. Larsson, G. Sterky, and S. Wall. 1985. The epidemiology of diabetes in Swedish children 0-14 years-a six-year prospective study. Diabetologia. 28:802808.

16. Owerbach, D., A. Lernmark, P. Platz, L. P. Ryder, L. Rask, P. A. Peterson, and J. Ludvigsson. 1983. HLA-D region $\beta$-chain DNA endonuclease fragments differ between HLA-DR identical healthy and insulin-dependent diabetic individuals. Nature (Lond.). 303:815-817.

17. Owerbach, D., B. Hägglöf, Å. Lernmark, and G. Holmgren. 1984. Susceptibility to insulin-dependent diabetes defined by restriction enzyme polymorphism of HLA-D region genomic DNA. Diabetes. 33:958-965.

18. Cohen, D., O. Cohen, A. Marcadet, C. Massart, M. Lathrop, I. Deschamps, J. Hors, E. Schuller, and J. Dausset. 1984. Class II HLADC $\beta$-chain DNA restriction fragments differentiate among HLA-DR2 individuals in insulin-dependent diabetes and multiple sclerosis. Proc. Natl. Acad. Sci. USA. 81:1774-1778.

19. Cohen-Haguenauer, O., E. Robbins, C. Massart, M. Busson, I. Deschamps, J. Hors, J. M. Lalouel, J. Dausset, and D. Cohen. 1984. A systematic study of HLA class II- $\beta$ DNA restriction fragments in insulindependent diabetes mellitus. Proc. Natl. Acad. Sci. USA. 82:3335-3339.

20. Owerbach, D., Å. Lernmark, L. Rask, P. A. Peterson, P. Platz, and A. Svejgaard. 1983. Detection of HLA-D/DR-related DNA polymorphism in HLA-D homozygous typing cells. Proc. Natl. Acad. Sci. USA. 80:3758-3761.

21. Böhme, J., M. Andersson, G. Andersson, E. Möller, P. A. Peterson, and L. Rask. 1985. HLA-DR $\beta$ genes vary in number between different DR specificities, whereas the number of $\mathrm{DQ} \beta$ genes is constant. J. Immunol. 135:2149-2155.

22. Cohen, D., I. Le Gall, A. Marcadet, M. P. Font, J. M. Lalouel, and J. Dausset. 1984. Clusters of HLA class II $\beta$ restriction fragments describe allelic series. Proc. Natl. Acad. Sci. USA. 81:7870-7874.
23. Andersson, M., J. Böhme, G. Andersson, E. Möller, E. Thorsby, L. Rask, and P. A. Peterson. 1984. Genomic hybridization with class II transplantation antigen cDNA probes as a complementary technique in tissue typing. Hum. Immunol. 11:57-67.

24. Böhme, J., B. Carlsson, J. Wallin, E. Möller, B. Persson, P. A. Peterson, and L. Rask. 1986. Only one DQ $\beta$ restriction fragment pattern of each DR specificity is associated with insulin-dependent diabetes. $J$. Immunol. 137:941-947.

25. Christian, B., H. Kromann, M. Christy, O. O. Andersen, and J. Nerup. 1979. Incidence of insulin-dependent diabetes mellitus (0-29 years at onset) in Denmark. Acta Med. Scand. Suppl. 624:54-60.

26. Michelsen, B., W. Kastern, Å. Lernmark, and D. Owerbach. 1985. Identification of and HLA-DC $\beta$-chain related genomic sequence associated with insulin-dependent diabetes. Biomed. Biochim. Acta. 44: 33-36.

27. Larhammar, D., L. Schenning, K. Gustafsson, K. Wiman, L. Claesson, L. Rask, and P. A. Peterson. 1982. Complete amino acid sequence of an HLA-DR antigen-like $\beta$ chain as predicted from the nucleotide sequence: Similarities with immunoglobulins and HLA-A, -B, and -C antigens. Proc. Natl. Acad. Sci. USA. 79:3687-3691.

28. Yanish-Perron, C., J. Vieira, and J. Messing. 1985. Improved M13 phage cloning vectors and host strains: nucleotide sequences of the M13mp18 and pUC19 vectors. Gene. 33:103-119.

29. Henikoff, S. 1984. Unidirectional digestion with exonuclease III creates targeted breakpoints for DNA sequencing. Gene. 28:351-359.

30. Hanahan, D. 1983. Studies on transformation of Escherichia coli with plasmids. J. Mol. Biol. 166:557-580.

31. Maniatis, T., E. F. Fritsch, and J. Sambrook. 1982. Molecular Cloning - a Laboratory Manual. Cold Spring Harbor Laboratory Press, Cold Spring Harbor, NY.

32. Chen, E. Y., and P. H. Seeburg. 1985. Supercoil sequencing: a fast and simple method for sequencing plasmid DNA. DNA (NY). 4: 165-170.

33. Larhammar, D., J. J. Hylding-Nielsen, B. Servenius, G. Andersson, L. Rask, and P. A. Peterson. 1983. Exon-intron organization and complete nucleotide sequence of a human major histocompatibility antigen DC $\beta$ gene. Proc. Natl. Acad. Sci. USA. 80:7313-7317.

34. Boss, J. M., and J. L. Strominger. 1984. Cloning and sequence analysis of the human major histocompatibility complex gene DC3 $\beta$. Proc. Natl. Acad. Sci. USA. 81:5199-5203.

35. Schenning, L., D. Larhammer, P. Bill, K. Wiman, A. K. Jonsson, L. Rask, and P. A. Peterson. 1984. Both $\alpha$ and $\beta$ chains of HLA-DC class II histocompatibility antigens display extensive polymorphism in their amino terminal domains. EMBO (Eur. Mol. Biol. Organ.) J. 3: 447-452.

36. Götz, H., H. Kratzin, F. P. Thinnes, C.-Y. Yang, T. Kruse, E. Pauly, S. Kolbel, G. Egbert, P. Wernet, and N. Hilschmann. 1983. Amino acid sequence comparison between $\mathrm{DR}$ and $\mathrm{DC}$ subclass antigens derived from a lymphoblastoid B cell line homozygous at the HLA loci. HoppeSeyler's Z. Physiol. Chem. 364:749-755.

37. Gregersen, P. K., M. Shen, Q.-L. Song, P. Marryman, S. Degar, T. Seki, J. Maccari, D. Goldberg, H. Murphy, J. Schwenzer, C. Y. Wang, R. J. Winchester, G. T. Nepom, and J. Silver. 1986. Molecular diversity of HLA-DR4 haplotypes. Proc. Natl. Acad. Sci. USA. 83:2642-2646.

38. Breatnach, R., and P. Chambon. 1981. Organization and expression of eukaryotic split genes coding for proteins. Annu. Rev. Biochem. 50:349-383.

39. Reinsmoen, N. L., and F. H. Bach. 1982. Five HLA-D clusters associated with HLA-DR4. Hum. Immunol. 4:249-258.

40. Nepom, B. S., G. T. Nepom, E. Michelson, P. Antonelli, and J. A. Hansen. 1983. Electrophoretic analysis of human HLA-DR antigens from HLA-DR homozygous cell lines. Proc. Natl. Acad. Sci. USA. 80: 6962-6966.

41. Sheehy, M. J., J. R. Rowe, and M. J. MacDonald. 1985. A particular subset of HLA-DR4 accounts for all or most of the DR4 association in Type I diabetes. Diabetes. 34:942-944.

42. Marcel, G., J. Titanus, B. Morolli, M. C. J. A. van Eggermond, 
G. M. T. Schreuder, R. R. P. de Vries, and M. J. Giphart. 1986. Dissection of HLA class II haplotypes in HLA-DR4 homozygous individuals. Immunogenetics. 23:333-340.

43. Bach, F. H., S. S. Rich, J. Barbosa, and M. Segall. 1985. Insulindependent diabetes-associated HLA-D region encoded determinants. Hum. Immunol. 12:59-64.

44. Deininger, P. L., D. J. Jolly, C. M. Rubin, T. Freidmann, and C. W. Schmid. 1981. Base sequence studies of 300 nucleotide renatured repeated human DNA clones. J. Mol. Biol. 151:17-33.

45. Bruseud, Ø., J. Jervell, and E. Thorsby. 1985. HLA-DR3 and -DR4 control T-lymphocyte responses to mumps and Coxsackie B4 virus: studies on patients with type 1 (insulin-dependent) diabetes and healthy subjects. Diabetologia. 28:420-426.

46. Babbitt, B. P., P. M. Allen, G. Matxueda, E. Habert, and E. R. Unanue. 1985. Binding of immunogenic peptides to Ia histocompatibility molecules. Nature (Lond.). 317:359-360.

47. Papadopoulos, G., and $\AA$. Lernmark. 1984. The immune response in individuals with HLA-DR specificities conferring susceptibility to insulin-dependent diabetes-a hypothesis. Diabetes Res. 1:3-11.

48. Lernmark, Å. 1984. Molecular biology of type 1 (insulin-dependent diabetes) mellitus. Diabetologia. 2268:195-203. 